\title{
Development of Drought Tolerant Rice Variety BRRI dhan66 for Rainfed Lowland Ecosystem of Bangladesh
}

\author{
M A Kader ${ }^{*}$, T L Aditya ${ }^{2}$, R R Majumder ${ }^{1}$, T K Hore ${ }^{1}$, A K M Shalahuddin ${ }^{1}$ and A Amin ${ }^{1}$
}

\begin{abstract}
A newly released drought tolerant rice variety BRRI dhan66 suitable for rainfed lowland ecosystem of Bangladesh is an improvement over existing drought tolerant rice varieties. The variety has satisfactorily been passed in the proposed variety trial conducted in the farmers' field. As a result, National Seed Board (NSB) approved this variety for commercial cultivation in the wet season (T. Aman) in 2014. It has modern plant type with $120 \mathrm{~cm}$ plant height and matures in 110-115 days. The important feature of this variety is higher drought tolerance during reproductive stage. It can produce 4.5-5.0 t/ha grain yield without irrigation during reproductive stage. It can produce satisfactory yield when soil moisture remains $<20 \%$ and perch water table depth is more than $70-80$ $\mathrm{cm}$ from the surface. The seed size of the variety is $24 \mathrm{~g}$ with intermediate long bold grain. It has long, wide and erect flag leaf with deep green colour. It is highly promising as a drought tolerant rice variety for cultivation in the drought prone area, which helps farmers' to get rid of huge economic loss and is contributing in sustaining food security.
\end{abstract}

Key words: Drought, wet season, BRRI dhan66, reproductive stage, perch water table, soil moisture

\section{INTRODUCTION}

Rice is the staple food for more than three billion people in Asia, where more than $90 \%$ of the world's rice is produced and consumed ( $\mathrm{Li}$ and $\mathrm{Xu}, 2007)$. It is grown worldwide in 154 million hectares ( $\mathrm{m} \mathrm{ha}$ ) and more than $45 \%$ of the area is in rainfed ecosystems, where yields are seriously affected by drought (IRRI, 2002). According to Ricepedia report, about 60 million hectares of rainfed lowlands supply about $20 \%$ of the world's rice production. The rice yield in these ecosystems is very low, 1.0$2.0 \mathrm{t} \mathrm{ha}^{-1}$ and is unstable due to erratic and unpredictable rainfall. With the changing climate, drought is becoming one of the major problems among other stresses which would affect rice production severely.

Drought is the most important source of climate-related risk for rice production in rainfed areas (Pandey et al., 2007). Drought affects about 100,000 hectares (250,000 acres) of land in Bangladesh particularly in Barind Tract and other northern districts during July to
September period. To maintain food security, development of drought tolerant varieties are needed for drought-prone Barind Tract and other areas. The drought tolerant rice varieties have also economic significance to other districts that are known as drought hot spots Kushtia, Magura, Chuadanga and Jashore, where rain is scanty and unpredictable during the last week of September and in October when rice needs water critically. Appropriately rice is grown in 27 million hectare of land worldwide in upland condition also facing draught stress. To counter this climate vulnerability, it is necessary to breed new rice cultivars with elevated drought tolerance.

Drought mitigation, through development of drought-tolerant rice varieties with higher yields suitable for water-limiting environments will be a key work to raise rice production and ensure food security to three billion people in Asia. The progress in genetic improvement of rice for water-limiting environments, however, has been slow and

1Plant Breeding Division, BRRI, 2Director (Research), BRRI, Gazipur, Bangladesh. ${ }^{*}$ Corresponding author's E-mail: abdulkaderbrri@yahoo.com 
limited (Evenson and Gollin, 2003) due to poor understanding of the inheritance, mechanisms of tolerance and lack of efficient techniques for screening breeding materials for drought tolerance (Khush, 2001). Characterization of drought environment, matching phenology, high potential yield and inbuilt drought tolerance are vital for successful crop production in water-limiting conditions. Drought types, particularly timing and intensity, are important in determining specific plant traits required to improve drought resistance. Drought stress induces a series of complex responses beginning with stress perception, signal transduction and manifestation of responses at the cellular, physiological, and developmental levels. The set of responses observed depends upon the crop stage, severity and duration of the stress. When evaluating the usefulness of traits to increase grain yield, it is important to consider phenological development, which has an overriding effect on the grain yield under water limiting condition (Fukai and Cooper, 1995). The reproductive development in plant is highly vulnerable to water deficit (Saini and Westgate, 2000). Yambao and Ingram (1988) reported yield reduction upto $70 \%$ upon imposing drought for 15 days at panicle initiation stage, and $88 \%$ and $52 \%$ reduction when stressed at flowering and grain filling stage respectively. Stress imposed during panicle initiation can delay or completely inhibit flowering, through inhibition of floral induction and development (Saini and Westgate, 2000). Within this period two sensitive peaks have been reported, one being the period around pollen mother cell meiosis and tetrad break up and the second is anthesis to initial stage of grain development. Pollen formation in rice is highly vulnerable to drought stress (Nguyen and Sutton, 2009). Stress at meiotic stage causes pollen sterility, failure of pollination, spikelet death or zygotic abortion, but female fertility is affected only under extreme stress.
Conventional breeding has been based on observed selection for yield. Most of the high yielding varieties- IR36, IR64, MTU1010, BR11, Swarna and Samba Mahsuri are grown in rainfed areas are preferred by the farmers due to their yield potential but are not tolerant to drought. These varieties give high yield during non-drought years, but there is drastic reduction when moderate drought appears and collapse completely in severe drought stress (Kumar et al., 2008). Other varieties which show some degree of resistance to drought reported from plateau region of Eastern India. Nam Sagui 19 is one of the important parental lines in breeding programme. Some of the successful cases of direct selection for grain yield under drought have been reported at IRRI (Kumar et al., 2008; Venuprasad et al., 2009). This breakthrough resulted in the development of several promising breeding lines for the rainfed lowland and upland (Mandal et al., 2010; Verulkar et al., 2010). Some of the varieties of rice for grain yield under drought conditions have been also released through direct selection those are Sahbhagidhan (India), Sukha dhan-1, Sukha dhan-2 and Sukha dhan3 (Nepal), BRRI dhan56 (Bangladesh), Sahod ulan-3, 5, 6, 8 and Katihan-8 (Philippines), Tarharra 1 (Nepal). These varieties perform well under drought as well as favourable years.

Multilocation testing of elite breeding lines has also allowed a better understanding of the genotypexenvironment $(\mathrm{G} \times \mathrm{E})$ interactions related to grain yield under reproductive-stage drought. In general, it has been observed that a majority of these lines perform best in their specific environments. A majority of these varieties were released in specific countries where they turned out to be the best performers. However, lines IR7437170-1-1 and IR74371-54-1-1 were released under three different names in India, Bangladesh, Nepal, Philippines and Nigeria respectivelyshowing the stability of performance of these 
lines across environments. Regardless of the complexity of grain yield under reproductivestage drought, lines selected under managed dry-season field experiments at IRRI were able to perform well in different countries. The success of this breeding programme pointed the adaptability of lines across regions in shallow lowland environments of different countries, and this validates the earlier prediction that $\mathrm{G} \times \mathrm{E}$ interactions can be handled more accurately within the different topography (shallow lowland, medium lowland, or deep lowland) in the rainfed ecosystem (Kumar et al., 2012).

The main objective of this study is to evaluate agronomic parameters of a drought tolerant rice variety BRRI dhan66 under controlled and natural condition and it's suitability for drought prone rainfed lowland rice ecosystem. The multi-location yield trials in multiple years demonstrated that BRRI dhan66 is more drought tolerant rice variety than existing one.

To release IR82635-B-B-75-2 as a drought tolerant variety BRRI dhan66, the yield and other parameters were observed which has been discussed very intensively in this study.

\section{MATERIALS AND METHODS}

BRRI dhan66 is an outcome of a single cross between two advanced breeding lines IR78875176-B-2 and IR78875-207-B-3 with a hope to develop a drought tolerant rice variety in International Rice Research Institute (IRRI). The pedigree of BRRI dhan66 is IR82635-B-B75-2. The fixed line was introduced from IRRI in 2010 and advanced yield trials were conducted in the different drought prone areas of Bangladesh until 2013.

The promising line was subjected to advanced yield trial (AYT) to evaluate specific and general adaptability with standard check BRRI dhan56 in on-station condition of nine regional stations of BRRI in randomized complete block (RCB) design with three replications in T. Aman 2011. After proper yield evaluation this material was subjected to advanced lines adaptive research trial (ALART) to evaluate specific and general adaptability with standard check BRRI dhan 56 in the farmers' field condition in T. Aman 2012 conducted by Adaptive Research Division (ARD) of BRRI. This genotype was tested for different physico-chemical properties, cooking qualities and best planting time, disease-insect reactions under natural condition were found out. Plant height, tillering ability were recorded from the ten random plants excluding border rows. Growth duration was counted from seedling to $80 \%$ grain maturity. Grain yield data was taken from $10 \mathrm{sq}-\mathrm{m}$ sample plot in each replication. In T. Aman 2013, IR82635-B-B-75-2 (BRRI dhan66) was evaluated by the National Seed Board of Bangladesh (NSB) in the nine locations of farmers' field of Bangladesh under field trial named proposed variety trial (PVT). Finally after proper evaluation the NSB team recommended IR82635-B-B-75-2 as a superior genotype in respect to drought tolerance for release as BRRI dhan66 in 2014.

\section{RESULTS AND DISCUSSION}

Table 1 shows the agro-morphological characteristics of BRRI dhan66. It has intermediate plant height and lodging tolerance. BRRI dhan66 has deep green, erect, long and wide flag leaf which facilitates maximum solar light uptake. The advanced yield trial of BRRI dhan66 with check variety BRRI dhan56 was conducted in five locations of Bangladesh. BRRI dhan66 showed the maximum yield (4.61 $\mathrm{t} / \mathrm{ha})$, followed by BRRI dhan56 (Table 1) in 2011. Importantly, BRRI dhan66 gave the highest (305) panicle $/ \mathrm{m}^{2}$ than BRRI dhan56 (286). The 1000 grain weight of BRRI dhan66 showed significant variation with BRRI dhan56. High yield is one of the 
prime objectives in developing modern rice varieties. BRRI dhan66 showed higher yield than the other breeding lines under drought condition in T. Aman 2011 season. One of the reasons of higher yield of BRRI dhan66 was due to its genetic potentiality of higher drought tolerance capacity than BRRI dhan56.

IR82635-B-B-75-2 (BRRI dhan66) and check variety BRRI dhan 56 were evaluated in 8 locations (Gazipur, Natore, Jhinaidah, Joypurhat, Kushtia, Rajshahi, Chapai Nawabgonj, Naogaon) in the farmers' field of Bangladesh in 2012. Table 2 shows the result. The highest grain yield was found for BRRI dhan66 (5.70 $\left.\mathrm{t} \mathrm{ha}^{-1}\right)$ followed by BRRI dhan56 $\left(5.10 \mathrm{t} \mathrm{ha}^{-1}\right)$ in Joypurhat. The result visualized the higher yield potentiality of BRRI dhan66 over the check genotype. On average BRRI dhan66 yielded $0.51 \mathrm{t} \mathrm{ha}^{-1}$ higher than BRRI dhan56. The genotype was almost disease free in some locations. The plant stature of the variety made the line lodging tolerant. Growth duration was found two days longer than the check variety BRRI dhan56. Farmers preferred BRRI dhan66 for better yield, shorter growth duration and importantly lodging tolerance as well as higher drought tolerance.
Table 3 shows performance of the IR82635-B-B-75-2 (BRRI dhan66) at on farm trial, T. Aman. IR82635-B-B-75-2 (BRRI dhan66) was evaluated by the National Seed Board (NSB) of Bangladesh in T. Aman 2013 season under on farm condition. The highest yield of the genotype was found 4.94 in Lalmonirhat followed by $4.82 \mathrm{t} /$ ha in Rangpur and $4.73 \mathrm{t} \mathrm{ha}^{-1}$ in Rajshahi. The grain yield indicated that the variety could produce more yield against drought stress. On average BRRI dhan66 produced $4.02 \mathrm{t} \mathrm{ha}^{-1}$ yield whereas BRRI dhan56 produced $3.23 \mathrm{t} \mathrm{ha}^{-1}$ yield. In other words, BRRI dhan 66 produced $0.79 \mathrm{t} \mathrm{ha}^{-1}$ more grain yield than BRRI dhan56 (Table 3). According to soil moisture and perch water table depth status BRRI dhan66 is more drought tolerant rice variety than BRRI dhan56 (Figs. 4 and 5). Growth duration of BRRI dhan66 was ranged from 107 days in Chapai Nawabganj to 117 days in Gazipur depending on the agro climatic situation in the T. Aman season. Mean growth duration of the variety was found 113 days which is three days longer than the check variety BRRI dhan56.

Table 1. Morphological and agronomical characters of the proposed variety, T. Aman 2011.

\begin{tabular}{|c|c|c|c|c|c|c|c|c|c|c|}
\hline \multirow[b]{2}{*}{ Designation } & \multirow[b]{2}{*}{$\begin{array}{c}\text { Plant } \\
\text { height }(\mathrm{cm})\end{array}$} & \multirow{2}{*}{$\begin{array}{c}\text { Growth } \\
\text { duration } \\
\text { (day) }\end{array}$} & \multirow{2}{*}{$\begin{array}{l}\text { Panicle per } \\
\mathrm{m}^{2}\end{array}$} & \multirow{2}{*}{$\begin{array}{c}1000 \text { grain } \\
\text { weight } \\
(\mathrm{gm})\end{array}$} & \multicolumn{6}{|c|}{ Grain Yield (t ha-1) } \\
\hline & & & & & Gazipur & Rangpur & Nilphamari & $\begin{array}{l}\text { Lalmonirh } \\
\text { at }\end{array}$ & Kurigram & Mean \\
\hline $\begin{array}{l}\text { IR82635-B-B-75- } \\
2 \text { (BRRI dhan66) }\end{array}$ & 120 & 114 & 305 & 25 & 4.9 & 4.3 & 4.8 & 4.6 & 4.5 & 4.6 \\
\hline $\begin{array}{l}\text { BRRI dhan56 } \\
\text { (ck) }\end{array}$ & 115 & 111 & 286 & 23 & 4.4 & 4.1 & 3.2 & 4.9 & 4.4 & 4.2 \\
\hline
\end{tabular}

Table 2. Performance of the proposed variety at different zonal trials, T. Aman 2012.

\begin{tabular}{|c|c|c|c|c|c|c|c|c|c|c|c|}
\hline \multirow[b]{2}{*}{ 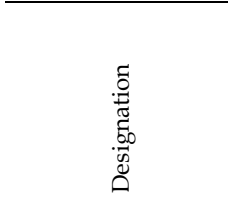 } & \multirow[b]{2}{*}{ 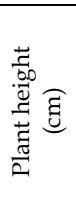 } & \multirow[b]{2}{*}{ 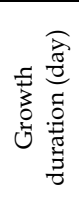 } & \multicolumn{9}{|c|}{ Grain yield (t ha-1) } \\
\hline & & & 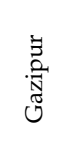 & 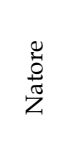 & 点 & 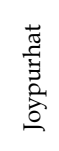 & 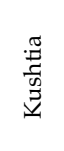 & 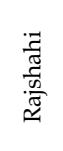 & 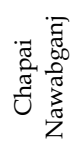 & $\begin{array}{l}\tilde{0} \\
\pi \\
0 \\
0 \\
Z \\
Z\end{array}$ & 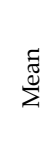 \\
\hline $\begin{array}{l}\text { IR82635-B-B-75-2 } \\
\text { (BRRI dhan66) }\end{array}$ & 118 & 111 & 4.88 & 4.51 & 5.10 & 5.70 & 5.42 & 5.21 & 5.14 & 5.66 & 5.20 \\
\hline BRRI dhan56 (Ck) & 116 & 108 & 4.48 & 4.23 & 4.35 & 5.10 & 4.79 & 4.39 & 5.11 & 5.10 & 4.69 \\
\hline
\end{tabular}


Table 3. Performance of the proposed variety at on farm trial, T. Aman 2013.

\begin{tabular}{|c|c|c|c|c|c|c|}
\hline \multirow[t]{2}{*}{ Location } & \multicolumn{2}{|c|}{$\begin{array}{l}\text { IR82635-B-B-75-2 } \\
\text { (BRRI dhan66) }\end{array}$} & \multicolumn{2}{|c|}{$\begin{array}{l}\text { BRRI dhan56 } \\
\text { (Check variety) }\end{array}$} & \multirow[t]{2}{*}{$\begin{array}{l}\text { LSD } \\
(0.05)\end{array}$} & \multirow[t]{2}{*}{ Remarks } \\
\hline & $\begin{array}{c}\text { Growth } \\
\text { duration } \\
\text { (Days) }\end{array}$ & $\begin{array}{l}\text { Grain } \\
\text { yield } \\
\text { (t/ha) }\end{array}$ & $\begin{array}{c}\text { Growth } \\
\text { duration } \\
\text { (Days) }\end{array}$ & $\begin{array}{l}\text { Grain } \\
\text { yield } \\
\left(\mathrm{t} \mathrm{ha}^{-1}\right)\end{array}$ & & \\
\hline Rajshahi (Godagari) & 113 & 4.11 & 115 & 3.19 & 0.631 & Significantly higher \\
\hline Rajshahi (Tanore) & 114 & 4.73 & 111 & 3.82 & 0.565 & Significantly higher \\
\hline $\begin{array}{l}\text { Chapai Nawabganj } \\
\text { (Gomostapur) }\end{array}$ & 107 & 2.51 & 106 & 1.48 & 0.452 & Significantly higher \\
\hline Naogaon (Pursha) & 111 & 4.07 & 107 & 3.31 & 0.392 & Significantly higher \\
\hline Naogaon (Neamotpur) & 113 & 2.58 & 109 & 1.94 & 0.364 & Significantly higher \\
\hline Rangpur (Sadar) & 114 & 4.82 & 111 & 3.93 & 0.615 & Significantly higher \\
\hline Nilphamari (Sadar) & 113 & 4.31 & 109 & 3.78 & 0.416 & Significantly higher \\
\hline Lalmonirhat (Sadar) & 114 & 4.94 & 110 & 3.91 & 0.715 & Significantly higher \\
\hline Dinajpur (Fulbaria) & 113 & 3.86 & 110 & 2.95 & 0.456 & Significantly higher \\
\hline Kushtia (Sadar) & 108 & 4.10 & 107 & 3.80 & 0.412 & $\begin{array}{c}\text { Not significant but } \\
\text { higher }\end{array}$ \\
\hline Gazipur (Sadar) & 117 & 4.17 & 115 & 3.46 & 0.213 & Significantly higher \\
\hline Mean & 113 & 4.02 & 110 & 3.23 & & \\
\hline
\end{tabular}

BRRI dhan66 showed tolerance to major diseases and insects under the natural field condition of Plant Breeding Division (Table 4). The variety showed bacterial infestation score 3 , meaning it is more or less tolerant to bacterial blight. The variety is found moderately tolerant to sheath blight disease (Table 4). The variety is also tolerant to stemborer for the dead heart and white head symptoms count. BRRI dhan56 also showed similar symptoms.
BRRI dhan66 produced optimum and higher yield when it was transplanted in first week of August and growth duration was 128 days. If it was transplanted in third week of August then it produced $5.06 \mathrm{t} /$ ha with 122 days growth duration and other transplanting dates were not suitable for BRRI dhan66. So the perfect date of transplanting ranged from first week of August to third week of August (Table 5).

Table 4. Reaction of the proposed variety against major diseases and insects under natural field condition.

\begin{tabular}{lcccc}
\hline Designation & BB & ShB & DH & WH \\
\hline $\begin{array}{l}\text { IR82635-B-B-75-2 } \\
\text { (BRRI dhan66) }\end{array}$ & 3 & 3 & 1 & 1 \\
BRRI dhan56 (ck) & 3 & 3 & 1 & 1 \\
\hline BB = Bacterial Blight, ShB = Sheath Blight, DH = Dead Heart, $\mathrm{WH}=$ White Head Disease and Insect severity scale $(0-9)$
\end{tabular}

Table 5. Effect of planting time on yield (t/ha) and growth duration (in the parenthesis) of the proposed variety.

\begin{tabular}{lcccccc}
\hline \multirow{2}{*}{ Designation } & \multicolumn{5}{c}{ Date of transplanting } \\
& 21 July & 6 August & 20 August & 4 September & 20 September & 5 October \\
\hline IR82635-B-B-75-2 & 4.38 & 5.68 & 5.06 & 4.06 & 2.53 & 0.682 \\
(BRRI dhan66) & $(129)$ & $(128)$ & $(122)$ & $(118)$ & $(111)$ & \\
& 2.82 & 2.88 & 3.28 & 2.88 & 2.69 & 0.701 \\
\multirow{2}{*}{ BRRI dhan56 (ck) } & $(120)$ & $(115)$ & $(113)$ & $(109)$ & $(103)$ & \\
\hline
\end{tabular}


Distinguishing characters of the candidate variety IR82635-B-B-75-2 (BRRI dhan66) compared to the check variety BRRI dhan56 are penultimate leaf pubescence of blade, anthocyanin colouration of lemma and palea, anthocyanin coloration of lemma and palea below apex, lemma anthocyanin colouration of apex, panicle length, number of effective tillers in plant, maturity duration (Table 6).

At $50 \%$ heading date time only $0.5 \%$ offtype was observed for both the lines. It indicated that the candidate variety IR82635-BB-75-2 is uniform according to International Union for the Protection of New Varieties of Plants (UPOV) standard.
In the test plots of two consecutive seasons trials, no remarkable variation and segregation were noted which implied the stability of the candidate varieties.

It was observed that BRRI dhan66 was more drought tolerant due to it's long root. The root length of BRRI dhan 66 was $61.0 \mathrm{~cm}$ where the root length of check variety BRRI dhan56 was $58.0 \mathrm{~cm}$. The grain weight per plant is also more than the check variety (Table 7). The leaf is deep green and plant is stronger under both controlled and natural drought stress condition (Figs. 1, 2 and 3).

Table 6. Distinctness between IR82635-B-B-75-2 (BRRI dhan66) with check variety BRRI dhan56.

\begin{tabular}{lcccccc}
\hline \multirow{2}{*}{ Characteristic } & \multicolumn{2}{c}{ BRRI dhan56 } & \multicolumn{2}{c}{ IR82635-B-B-75-2 } & Remark \\
& Code & State & Code & State & \\
\hline Penultimate leaf pubescence of blade & 1 & Absent & 5 & Medium & Distinct \\
$\begin{array}{l}\text { Anthocyanin coloration of Lemma \& Palea } \\
\text { Anthocyanin coloration of Lemma \& palea below }\end{array}$ & 5 & Medium & 1 & Absent & Distinct \\
$\begin{array}{l}\text { apex } \\
\text { Lemma anthocyanin coloration of apex }\end{array}$ & 5 & Medium & 1 & Absent & Distinct \\
$\begin{array}{l}\text { Panicle length } \\
\text { Number of effective tillers in plant }\end{array}$ & 3 & Weak & 1 & Absent & Distinct \\
Time of maturity & 7 & Medium & 7 & Long & Distinct \\
Grain wt. of 1000 fully developed grains (at 12\%) & 5 & Medium & 7 & High & Distinct \\
\hline
\end{tabular}

Table 7. Evaluation of proposed variety under controlled drought condition, BRRI, Gazipur, T. Aman $2012-13$.

\begin{tabular}{lccccc}
\hline \multirow{2}{*}{ Designation } & $\begin{array}{c}\text { Root length } \\
(\mathrm{cm})\end{array}$ & \multicolumn{2}{c}{ Grain wt. (g) / Plant } & \multicolumn{2}{c}{ \%Sterility } \\
\hline IR82635-B-B-75-2 (BRRI dhan66) & 61.0 & 15.51 & 44.0 & 64.2 & 10.9 \\
BRRI dhan56 (ck) & 58.0 & 14.3 & 43.6 & 63.3 & 18.2 \\
\hline
\end{tabular}



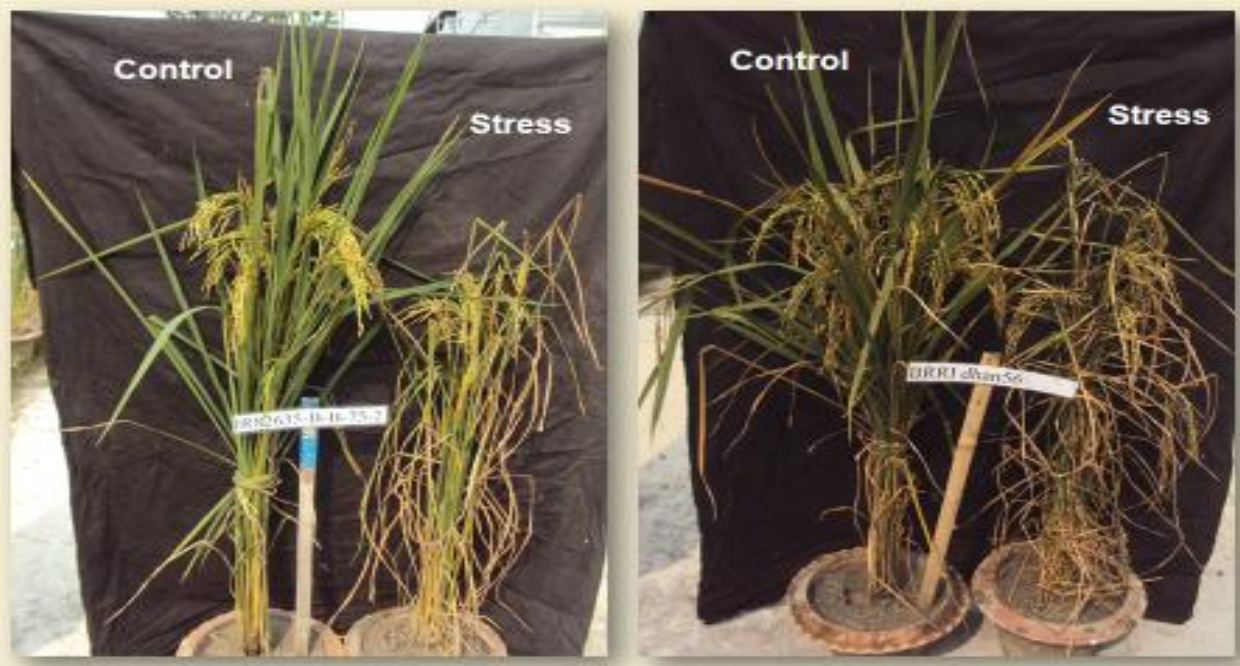

Fig. 1. Front view of IR82635-B-B-75-2 (BRRI dhan66) with BRRI dhan56 screened under controlled drought condition in BRRI.
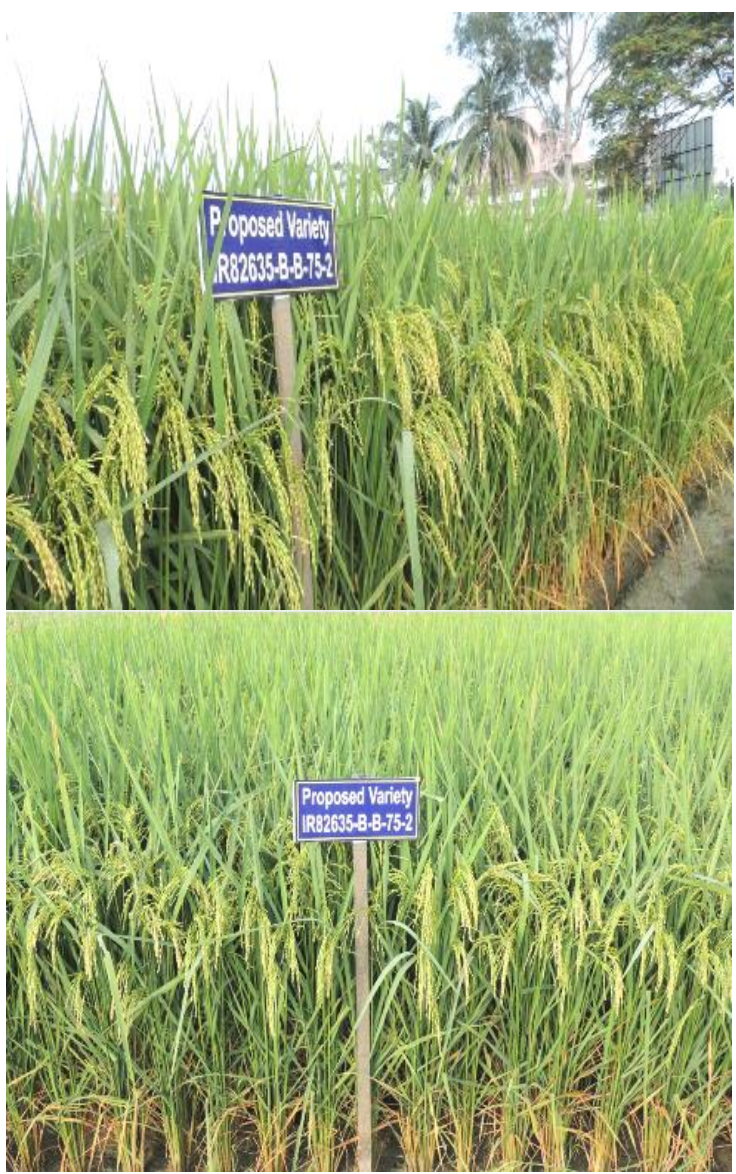

Fig. 2. BRRI dhan66 under rainfed condition.

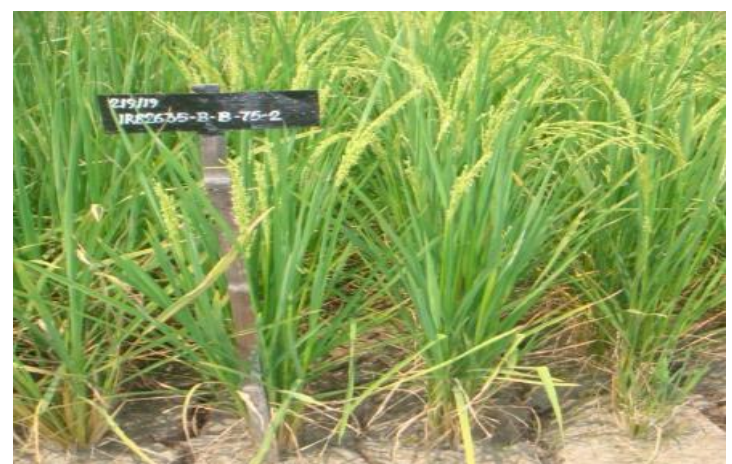

Fig. 3. BRRI dhan66 under natural drought condition.

During T. Aman 2013, soil moisture status of the experiment field, with proposed variety BRRI dhan66 and check variety BRRI dhan56, was observed very low (15-10\%) during reproductive stage under controlled drought condition in BRRI (Fig. 4). Perch water table depth was obtained at below 30-35 cm from soil surface in the experiment field of proposed variety BRRI dhan66 with check variety BRRI dhan56 under controlled drought condition in BRRI (Fig. 5). In T. Aman 2011, ground water table depth $(\mathrm{cm})$ of field at reproductive stage in Alimganj, Paba, Rajshahi was below 20-80 $\mathrm{cm}$ from soil surface and soil moisture was 6$10 \%$ (Figs. 6 and 7). So, it was proved that BRRI dhan66 has higher drought tolerance.

Development of Drought Tolerant Rice Variety 51 


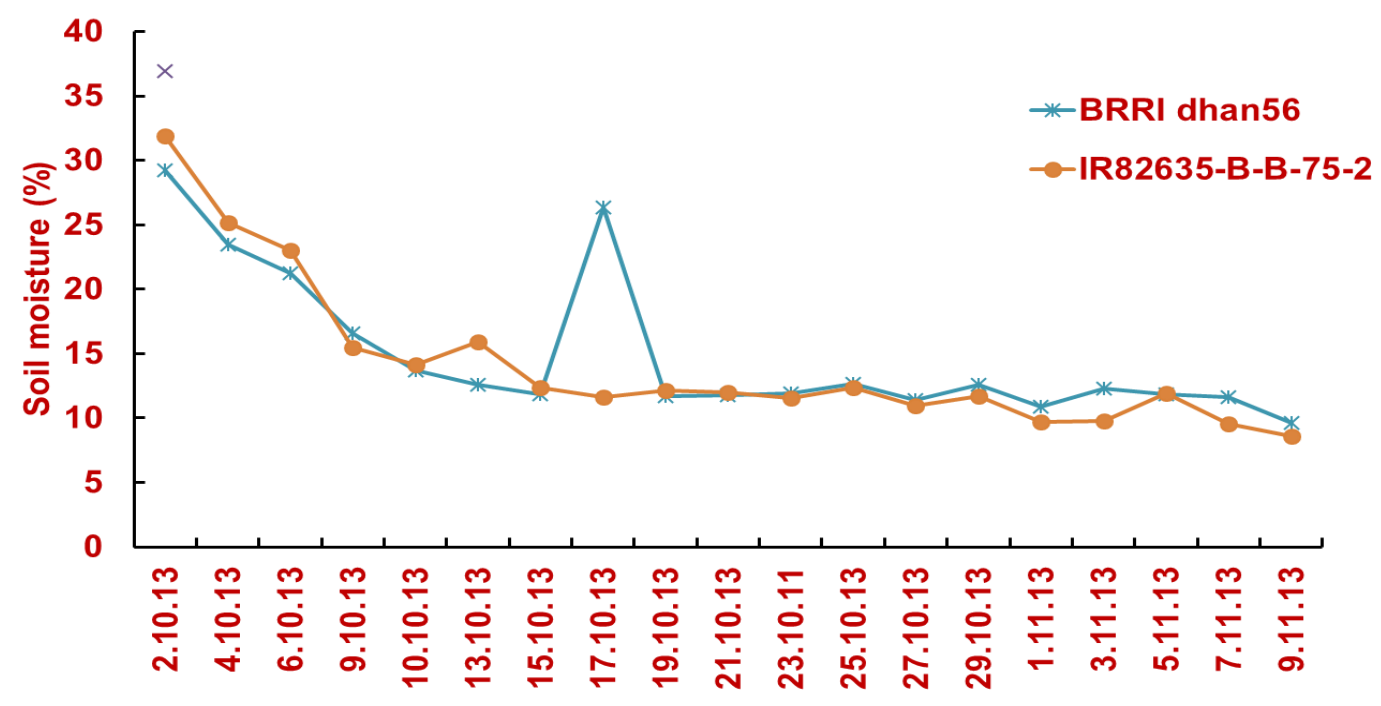

Days after withholding of water

Fig. 4. Soil moisture status of proposed variety BRRI dhan66 with check variety BRRI dhan56 under controlled drought condition in BRRI, 2013.

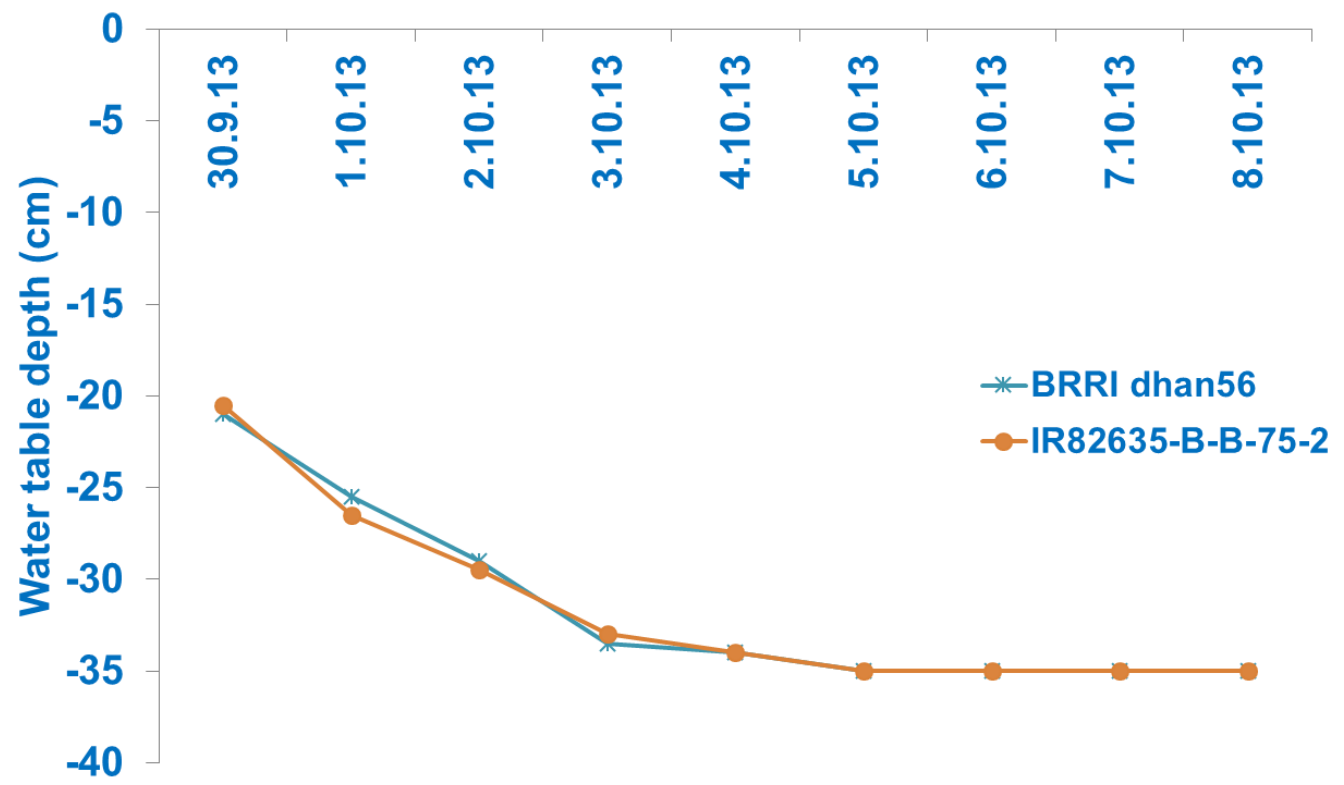

Date (starting from withholding of water )

Fig. 5. Perch water table depth status of proposed variety BRRI dhan 66 with check variety BRRI dhan56 under controlled drought condition in BRRI, 2013. 


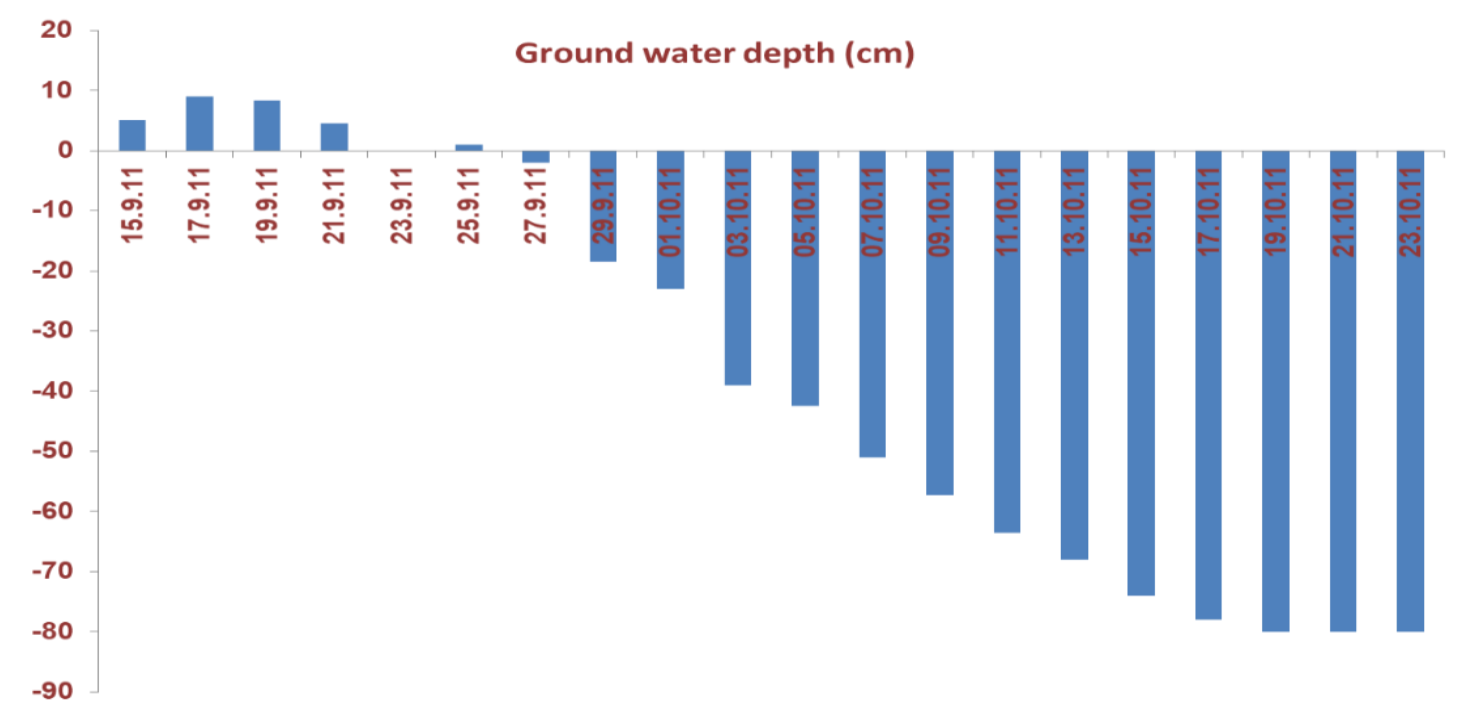

* 21 rainless days

Fig. 6. Ground water table depth $(\mathrm{cm})$ of proposed variety at reproductive stage in Alimganj at Paba upazila in Rajshahi, T. Aman 2011.

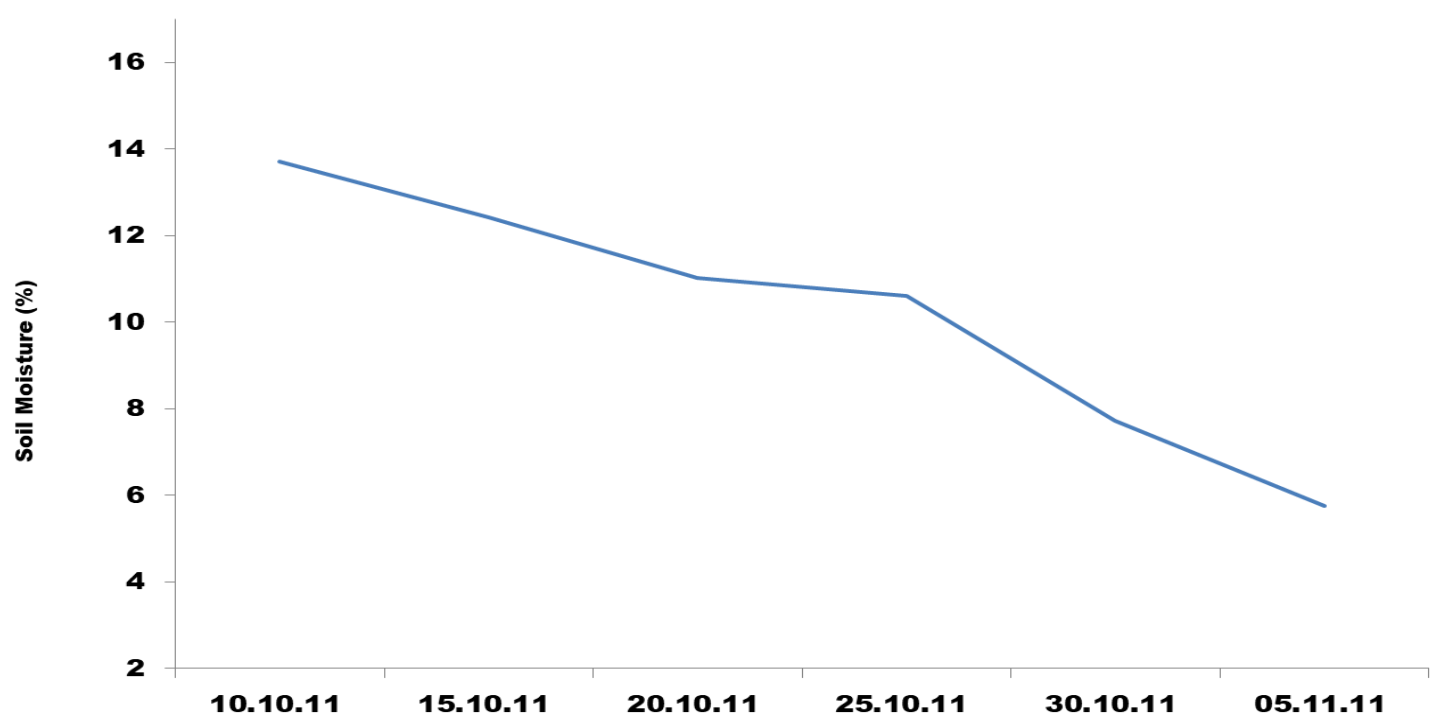

Fig. 7. Soil moisture (\%) of proposed variety at reproductive stage in Alimganj at Paba upazila in Rajshahi, T. Aman 2011.

BRRI dhan66 has medium bold grain having length-breadth ratio of 2.7 which is similar with BRRI dhan56. The milling outturn of the variety was $65.6 \%$ with the head rice recovery $59.2 \%$ which was better than the other varieties (Table 8). But BRRI dhan66 has $10.8 \%$ protein where BRRI dhan 56 has $8.4 \%$ protein. Table 8 presents the physicochemical properties of BRRI dhan66 indicating the grain characteristics of BRRI dhan66. Figure 8 shows the paddy and husked rice of BRRI dhan 66 and BRRI dhan56. 
Table 8. Physicochemical properties of BRRI dhan63.

\begin{tabular}{|c|c|c|c|c|c|c|c|c|c|}
\hline \multirow[t]{2}{*}{ Designation } & \multirow{2}{*}{$\begin{array}{c}\text { Milling } \\
\text { yield (\%) }\end{array}$} & \multirow{2}{*}{$\begin{array}{c}\text { Head } \\
\text { rice } \\
\text { yield }(\%)\end{array}$} & \multicolumn{4}{|c|}{ Decorticated grain } & \multirow[t]{2}{*}{$\mathrm{ER}^{*}$} & \multirow{2}{*}{$\begin{array}{c}\text { Protein } \\
(\%)\end{array}$} & \multirow{2}{*}{$\begin{array}{c}\text { Amylose } \\
(\%)\end{array}$} \\
\hline & & & $\begin{array}{l}\text { Length } \\
(\mathrm{mm})\end{array}$ & $\begin{array}{l}\text { Breadth } \\
(\mathrm{mm})\end{array}$ & $\begin{array}{l}\mathrm{L} / \mathrm{B} \\
\text { Ratio }\end{array}$ & $\begin{array}{c}\text { Size and } \\
\text { shape }\end{array}$ & & & \\
\hline $\begin{array}{l}\text { IR82635-B-B- } \\
\text { 75-2 (BRRI } \\
\text { dhan66) }\end{array}$ & 65.6 & 59.2 & 6.0 & 2.2 & 2.7 & $\begin{array}{l}\text { Medium } \\
\text { bold }\end{array}$ & 1.4 & 10.8 & 23.0 \\
\hline $\begin{array}{l}\text { BRRI dhan56 } \\
\text { (Ck) }\end{array}$ & 66.0 & 57.7 & 6.1 & 2.2 & 2.7 & $\begin{array}{l}\text { Medium } \\
\text { bold }\end{array}$ & 1.3 & 8.4 & 23.0 \\
\hline
\end{tabular}

${ }^{*}$ ER: Elongation ratio

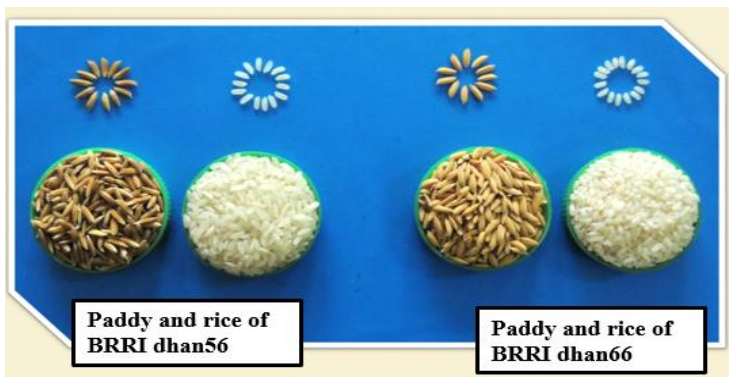

Fig. 8. Comparative view of paddy and husked rice of BRRI dhan66 and BRRI dhan56.

\section{CONCLUSION}

Drought tolerant HYV at reproductive phase in rainfed lowland rice ecosystem is highly demanding. BRRI dhan66 can give $0.5-1.0 \mathrm{t} \mathrm{ha}^{-1}$ more yield than BRRI dhan56 under drought prone environments of Bangladesh. Adaptability tests of this variety under multilocation trials in the farmers' field showed satisfactory performance with respect to grain yield and some yield contributing parameters. It is anticipated that this drought tolerant rice variety will contribute to the national gross domestic product (GDP) and also alleviating poverty from drought prone northern region of Bangladesh and thus will contribute in sustaining food security.

\section{ACKNOWLEDGEMENT}

The author is thankful to technical assistance from scientists of Plant Breeding, Adaptive Research, Plant Pathology, Plant Physiology, Entomology, Grain Quality and Nutrition, Soil Science and Agronomy division of BRRI. BRRI authorities are gratefully acknowledged for providing supports in this research activity.

\section{REFERENCES}

Evenson, R E and G Gollin. 2003. Assessing the impact of the green revolution, 1960-2000. Science 300:758762.

Fukai, S and M Cooper. 1995. Development of drought resistant cultivars using physio-morphological traits in rice. Field Crops Research 40:67-86.

IRRI (International Rice Research Institute). 2002. Rice almanac. IRRI-WARDA-CIAT-FAO, Los Banos

Khush, G S. 2001. Green revolution: the way forward. Nature Rev. 2:815-822.

Kumar, A, S B Verulkar, N P Mandal, M Variar, V D Shukla, J L Dwivedi, B N Singh, O N Singh, P Swain, A K Mall, S Robin, R Chandrababu, A Jain, S M Haefele, H P Piepho and A Raman. 2012. High-yielding, drought-tolerant, stable rice genotypes for the shallow rainfed lowland drought-prone ecosystem. Field Crops Research, 133: 37-47.

Kumar, A, J Bernier, S Verulkar, H R Lafitte, and G N Atlin. 2008. Breeding for drought tolerance: Direct selection for yield, response to selection 
and use of drought tolerant donors in upland and lowland-adapted populations. Field Crop Research. 107: 221-231.

Li, Z K, and J L Xu. 2007. Breeding for drought and salt tolerant rice (Oryza sativa L.): progress and perspectives. In: Jenks M A et al (eds) Advances in molecular breeding toward drought and salt tolerant crops. Springer, USA, 531-564.

Mandal, N P, P K Sinha, M Variar, V D Shukla, P Perraju, A Mehta, A R Pathak, J L Dwivedi, S P S Rathi, S Bhandarkar, B N Singh, D N Singh, S Panda, N C Mishra, Y V Singh, R Pandya, M K Singh, R B S Sanger, J C Bhatt, R K Sharma, A Raman, A Kumar and G N Atlin. 2010. Implications of genotype $x$ input interactions in breeding superior genotypes for favourable and unfavourable rainfed upland environments. Field Crops Research, 118: 135-144.

Nguyen, G N and B G Sutton. 2009. Water deficit reduced fertility of young microspores resulting in a decline of viable mature pollen and grain set in rice. J Agron Crop Science, 195: 11-18.

Pandey, S, H Bhandari, and B Hardy. 2007. Economic costs of drought and rice farmers' coping mechanisms: a cross-country comparative analysis. Los Baños (Philippines): International Rice Research Institute. 203 p.

Saini, H S and M E Westgate. 2000. Reproductive development in grain crops during drought. $A d v$ Agron 68:59-98.

Venuprasad, R B, M E Dalid, C O Bernier, J Kumar and G N Atlin. 2009. Genetic loci responding to two cycles of divergent selection for grain yield under drought stress in a rice breeding population. Euphytica. 167:261-269.

Verulkar, S B, N P Mandal, J L Dwivedi, B N Singh, P K Sinha, R N Mahato, P Swain, P Dongre, D Payasi, O N Singh, L K Bose, S Robin, R C Babu, S J Senthil, H E Shashidhar, S Hittalmani, C V Cruz, T Paris, R Hijsman, A Raman, S Haefele, R Serraf, G N Atlin and A Kumar. 2010. Breeding resilient and productive rice genotypes adapted to drought-prone rainfed ecosystems of India. Field Crops Research, 117: 197- 208.

Yambao, E B and K T Ingram. 1988. Drought stress index for rice. Philippine Journal of Crop Science, 193: 105-111. 
